\title{
Surface Runoff Assessment of Koraput District in Eastern Ghats High Land Zone of Odisha
}

\author{
B. S. Naik ${ }^{1 *}$, J. C. Paul ${ }^{2}$, B. Panigrahi ${ }^{2}$, B. C. Sahu ${ }^{2}$, A. P. Sahu ${ }^{2}$ and Ravi Dupdal ${ }^{1}$ \\ ${ }^{1}$ ICAR-IISWC, Research Centre, Hospet Road, Bellary-583104, Karnataka, India \\ ${ }^{2}$ Department of Soil and Water Conservation Engineering, College of Agricultural \\ Engineering and Technology, OUAT, Bhubaneswar-751003, Odisha, India \\ *Corresponding author
}

\section{A B S T R A C T}

\section{Keywords}

Curve number;

Eastern Ghats region, Hydrologic soil group, Runoff

Article Info

Accepted:

17 January 2021

Available Online:

10 February 2021
Surface runoff was assessed for Koraput district located in Eastern Ghats high land zone of Odisha from rainfall events for 27 years (from 1986 to 2012) using USDA Soil Conservation Service-Curve Number (SCS-CN) method. Highest annual runoff of $681.5 \mathrm{~mm}$ (26.5\% of rainfall) and lowest runoff of $202.7 \mathrm{~mm}$ (22.3\% of rainfall) was observed in the year 1990 and 2009, respectively. When month wise compared, highest rainfall and runoff is found in the month of July \{384.5 mm and $94.1 \mathrm{~mm}(24.5 \%)\}$ followed by August $\{335.4 \mathrm{~mm}$ and $75.4 \mathrm{~mm}$ $(22.5 \%)\}$ and September $\{232.8 \mathrm{~mm}$ and $61 \mathrm{~mm}(26.2 \%)\}$ and it indicates maximum runoff is generated during kharif (June to September) resulting from higher rainfall. Using the available best fit probability distributions, expected month wise runoff at $10,20,30,40,50,60,70,80$ and $90 \%$ probabilities were also estimated. The dependable annual runoff is determined as $10 \%$ and $15 \%$ of total annual normal rainfall at 80 and $60 \%$ probability level and it results in total potential surface runoff of 45007.2 ha-m and 65578.88 ha-m, respectively from the cultivable catchment area of the Koraput district.

\section{Introduction}

For agriculture, water is one of the prime natural resources and it needs to be utilized judiciously. Rainfall and runoff are the two important components of hydrologic cycle. Runoff plays a major role in water resources applications, and its occurrence and quantity are dependent on the rainfall characteristics, i.e., the intensity, duration and distribution of rainfall. Besides these rainfall characteristics, there are many catchment specific factors i.e. soil type, vegetation cover, slope and catchment type, which have a direct effect on the occurrence and volume of runoff. The Soil Conservation Service Curve Number (SCS- 
CN) method is widely used for predicting direct runoff volume for a given rainfall event. This method was originally developed by the National Resources Conservation Service (NRCS), United States Department of Agriculture in 1969. The $\mathrm{CN}$ for a drainage basin is estimated using a combination of land use, soil, and antecedent soil moisture condition (AMC). It is a quantitative description of land use, land cover and soil complex characteristics of a watershed (SCS, 1972) and is widely used hydrological model for runoff estimation. This SCS-CN includes an empirical relationship for estimating initial abstraction and runoff as a function of soil type and land-use. The $\mathrm{CN}$ is also an index that represents the runoff potential of the watershed. Many researchers has used this SCS-CN method for predicting the runoff potential as it is well-established, simple to use, and widely accepted (Mishra et al., 2006; Kumar et al., 2010; Panigrahi et al., 2010; Somashekar et al., 2011; Nagarajan et al., 2013; Muthu and Shanti, 2015). Though this method is mostly used but it does not consider the impact of rainfall intensity and its temporal distribution, it does not address the effects of spatial scale and the effect of adjacent moisture condition.

Under the present study, the surface runoff potential of Koraput district located in the Eastern Ghats high land zone of Odisha was estimated using widely adopted SCS-CN method.

\section{Materials and Methods}

Koraput district is located in the extreme southern part of Odisha in the eastern plateau and hill region (Agro- Climatic Zone VII) in Eastern Ghats (Fig. 1) comprising total geographical area of 8.81 lakh ha. It lies between Latitudes of $18^{\circ} 15^{\prime} 00^{\prime \prime}$ to $19^{\circ} 12^{\prime}$ ' $30^{\prime \prime}$ North and Longitude of $82^{\circ} 08^{\prime} 04^{\prime \prime}$ to $83^{\circ}$ 24 ' 46" East with altitude varies from 500 to
$1600 \mathrm{~m}$ above mean sea level (Naik et al., 2014). The normal annual rainfall in the district amounts to $1567 \mathrm{~mm}$ occurring in 83.9 rainy days. June to September is the usual wet period, where $79 \%$ rainfall is recorded in 62.4 rainy days due to south west monsoon. The major soil types found in the district are red, alluvial, mixed red and yellow having sandy loam to sandy clay loam texture.

Major crops grown in the district are paddy, ragi, maize, niger, horse gram, black gram, field pea and arhar. The land use details of the Koraput district are given in Table 1. This district is endowed with potentially rich natural resources but subjected to many inherent problems like undulating topography, fragile steep slopes, high and intense rainfall, heavy runoff and severe soil erosion (Naik et $a l ., 2015)$. Though the district receives pretty amount of rainfall (1567 mm per annum), it suffers from acute water scarcity during post monsoon season. To deal with this, there is abundant scope for harvesting of huge amount of runoff which goes waste during rainy season. Since runoff is an important input for planning any water resources development in the region, it has to be quantified.

Source: Odisha Agricultural Statistics 2010-11 (Govt. of Odisha, 2012).

The SCS-CN model developed by United States Department of Agriculture (USDA) computes direct runoff through an empirical equation that requires the rainfall and a watershed coefficient as inputs. The watershed coefficient is called as the curve number $(\mathrm{CN})$, which represents the runoff potential of the land cover soil complex. This model involves relationship between land use, hydrologic soil group and curve number. The SCS model computes direct runoff using the following relationships (Subramanya, 1994)

$\mathrm{S}=(25400 / \mathrm{CN})-254(1)$ 
$\mathrm{Q}=(\mathrm{P}-0.2 \mathrm{~S}) 2 /(\mathrm{P}+0.8 \mathrm{~S})(2)$

Where,

$\mathrm{Q}=$ Surface runoff in $\mathrm{mm}, \mathrm{P}=$ Rainfall in $\mathrm{mm}$, $\mathrm{S}=$ Storage capacity in $\mathrm{mm}$,

$\mathrm{CN}=$ Value of curve number $(\mathrm{CN})$ depending on land use conditions and hydrologic soil groups.

Applying above relationship (Eqn.1 \& 2), runoff was computed using daily rainfall data of Koraput district for 27 years (from 1986 to 2012). Runoff yield from daily rainfall events and then using it, monthly and annual runoff yield for above 27 years was determined.

The month wise runoff computed for the said period was again analyzed using different available probability distributions models $i$.e. Normal, Log normal, Weibull, Gamma, Exponential, Log normal 3 parameter, Pearson, Log Pearson, Generalized pareto, Extreme value Type III, Gumbel EV1 (Extreme value maximum), Gumbelmaximum (MOM) and Generalized extreme value and the best fit probability distributions were found out based on lowest Chi-square value. Using these best fit probability distributions, expected month wise runoff for the said period at different probabilities i.e. 10, 20, 30, 40, 50, 60, 70, 80 and 90\% were estimated. For quantifying the dependable volume of runoff from the cultivable catchment area of the region, only $60 \%$ and $80 \%$ probability levels were considered from June to February only.

\section{Results and Discussion}

\section{Rainfall and runoff yield}

Daily rainfall data for 27 years (from 1986 to 2012) was analysed, and then monthly and annual rainfall was obtained. Accordingly using daily rainfall events, the resulting monthly and annual runoff yield were estimated from SCS-CN method and is presented in Fig. $2 \& 3$. It reveals that highest rainfall of $2572 \mathrm{~mm}$ and resulting runoff of $681.5 \mathrm{~mm}(26.5 \%)$ occurred in the year 1990, and lowest rainfall of $910.8 \mathrm{~mm}$ and resulting runoff of $202.7 \mathrm{~mm}(22.3 \%)$ occurred in the year 2009. When month wise compared, highest rainfall and runoff was found in the month of July $\{384.5 \mathrm{~mm}$ and $94.1 \mathrm{~mm}$ $(24.5 \%)\}$ followed by in the month of August $\{335.4 \mathrm{~mm}$ and $75.4 \mathrm{~mm}(22.5 \%)\}$ and September $\{232.8 \mathrm{~mm}$ and $61 \mathrm{~mm}(26.2 \%)\}$. It is observed that major portion of the annual rainfall is received during kharif (June to September) and it generates maximum runoff during the said period which mostly goes as waste. It indicates that plenty of runoff is available in the month of June, July, August and September as higher rainfall is received during these four months only compared to rest of year.

\section{Runoff analysis with probability distributions models}

The month wise runoff computed from 1986 to 2012 was analyzed using different available probability distributions i.e. Normal, Log normal, Weibull, Gamma, Exponential, Log normal 3 parameter, Pearson, Log Pearson, Generalized pareto, Extreme value Type III, Gumbel EV1 (Extreme value maximum), Gumbel-maximum (MOM) and Generalized extreme value, and the best fit probability distributions were determined. Based on lowest Chi-square value, the best fit probability distribution found was Log Pearson for the month of June, July, September, November and December, Log normal 3 parameter for the month of August and January, Generalized extreme value for the month of October and Gumbel-maximum for the month of February, respectively (Table 2). 
Utilizing the above best fit probability distributions obtained for different months, the expected month wise runoff was again estimated at different probability levels i.e. 10 , $20,30,40,50,60,70,80$ and $90 \%$ and are given in Table 3.

The expected annual runoff determined at 10 , $20,30,40,50,60,70,80$ and $90 \%$ probability levels are 717.1, 521.5, 414.1, 341, 284.4, $238.2,196.1,156.7$ and $114.7 \mathrm{~mm}$ with decreasing trend with respect to the increase in probability percentage. During the entire year, starting from the month June up to September, appreciable runoff yield is expected at more than $60 \%$ probability level due to higher rainfall. When compared among months, maximum runoff is expected during the month of July followed by August, September and June as higher rainfall is received in the month of June compared to August, September and June. At 80 and $60 \%$ probability, the annual runoff expected is most dependable and it is determined as $156.7 \mathrm{~mm}(10 \%)$ and $238.2 \mathrm{~mm}$ (15\%) out of total annual normal rainfall of $1567.2 \mathrm{~mm}$. Accordingly, taking into consideration of the total cultivable land, the total surface runoff potential of the Koraput district is estimated to be 45007.2 ha-m (at 80 $\%$ probability level) and 65578.88 ha-m (at $60 \%$ probability level), respectively. It indicates there is abundant scope for runoff harvesting by constructing more numbers of water harvesting structures and other suitable soil and water conservation measures. It is estimated that if surface runoff yield at $80 \%$ probability level is harvested through storage structures, it can irrigate 450072 ha of crop field with two life saving irrigations of $5 \mathrm{~cm}$ each during water scarcity or post monsoon period. Similarly, runoff harvested at $60 \%$ probability level can irrigate 655788.8 ha of crop field by supporting at least two life saving irrigations of $5 \mathrm{~cm}$ each.

The SCS-CN is found to be a quantitative description of land use / land cover / soil complex characteristics of a watershed and is widely used hydrological model for estimating runoff using rainfall and curve number $(\mathrm{CN})$. It is also a proven index that represents the watershed runoff potential.

Table.1 Land use pattern of the Koraput district

\begin{tabular}{|c|c|c|}
\hline S.No & Land use & Area ('000 ha) \\
\hline $\mathbf{1}$ & Forest area & 188 \\
\hline $\mathbf{2}$ & Land under misc. tree crops and groves & 17 \\
\hline $\mathbf{3}$ & Permanent pastures & 45 \\
\hline $\mathbf{4}$ & Culturable waste & 44 \\
\hline $\mathbf{5}$ & Land put to non- agricultural use & 54 \\
\hline $\mathbf{6}$ & Barren and unculturable land & 210 \\
\hline $\mathbf{7}$ & Current fallows & 36 \\
\hline $\mathbf{8}$ & Other fallows & 19 \\
\hline $\mathbf{9}$ & Net sown area & 268 \\
\hline $\mathbf{1 0}$ & Total geographical area & 881 \\
\hline
\end{tabular}


Table.2 Month wise best fit probability distributions of runoff

\begin{tabular}{|c|c|}
\hline Month & $\begin{array}{c}\text { Best fit distribution } \\
\text { (Chi-square value is minimum) }\end{array}$ \\
\hline January & Log normal 3 parameter \\
February & Eumbel-maximum (MOM) \\
\hline March & Exponential \\
\hline April & Extreme value type III \\
\hline May & Log Pearson \\
\hline June & Log Pearson \\
\hline July & Log normal 3 parameter \\
\hline August & Log Pearson \\
\hline September & Generalized extreme value \\
\hline October & Log person \\
\hline November & Log Pearson \\
\hline December & \\
\hline
\end{tabular}

Table.3 Expected month wise runoff $(\mathrm{mm})$ at different probability levels

\begin{tabular}{|c|c|c|c|c|c|c|c|c|c|}
\hline \multirow[t]{3}{*}{ Month } & \multicolumn{9}{|c|}{ Probability level (\%) } \\
\hline & 90 & 80 & 70 & 60 & 50 & 40 & 30 & 20 & 10 \\
\hline & \multicolumn{9}{|c|}{ Runoff in mm } \\
\hline Jan & 0 & 0 & 0 & 0 & 0 & 1.80 & 2.97 & 6.85 & 12.64 \\
\hline Feb & 0 & 0 & 0 & 1.49 & 2.36 & 3.06 & 3.79 & 4.67 & 6.02 \\
\hline Mar & 0 & 0.13 & 1.11 & 2.24 & 3.57 & 5.21 & 7.32 & 10.23 & 15.37 \\
\hline Apr & 0 & 3.24 & 6.04 & 8.29 & 10.37 & 12.45 & 14.69 & 17.34 & 21.04 \\
\hline May & 2.46 & 5.23 & 8.36 & 11.97 & 16.24 & 21.47 & 28.22 & 37.72 & 53.97 \\
\hline Jun & 10.74 & 15.92 & 20.81 & 26.18 & 32.55 & 40.65 & 51.92 & 69.79 & 107.10 \\
\hline July & 41.71 & 52.62 & 62.22 & 71.80 & 82.07 & 93.81 & 108.27 & 128.06 & 161.67 \\
\hline Aug & 32.27 & 39.40 & 46.14 & 53.24 & 61.26 & 70.89 & 83.32 & 101.32 & 134.18 \\
\hline Sept & 23.94 & 29.94 & 35.54 & 41.44 & 48.12 & 56.20 & 66.82 & 82.58 & 112.60 \\
\hline Oct & 3.53 & 8.38 & 12.47 & 16.47 & 20.7 & 25.5 & 31.4 & 39.53 & 53.62 \\
\hline Nov & 0 & 1.79 & 3.36 & 5.10 & 7.17 & 9.76 & 13.22 & 18.35 & 27.73 \\
\hline Dec & 0 & 0 & 0 & 0 & 0 & 0.24 & 2.12 & 5.01 & 11.20 \\
\hline
\end{tabular}


Fig.1 Location map of Koraput district

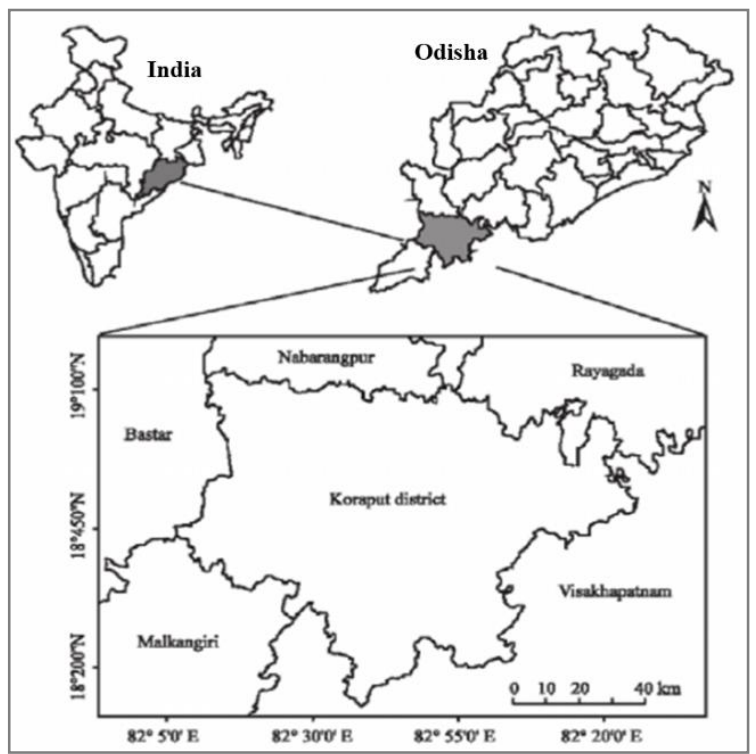

Fig.2

Fig.2. Year wise rainfall and runoff yield of Koraput district

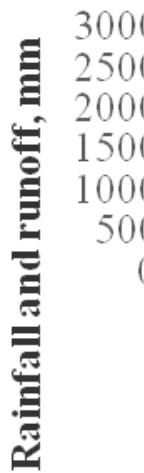

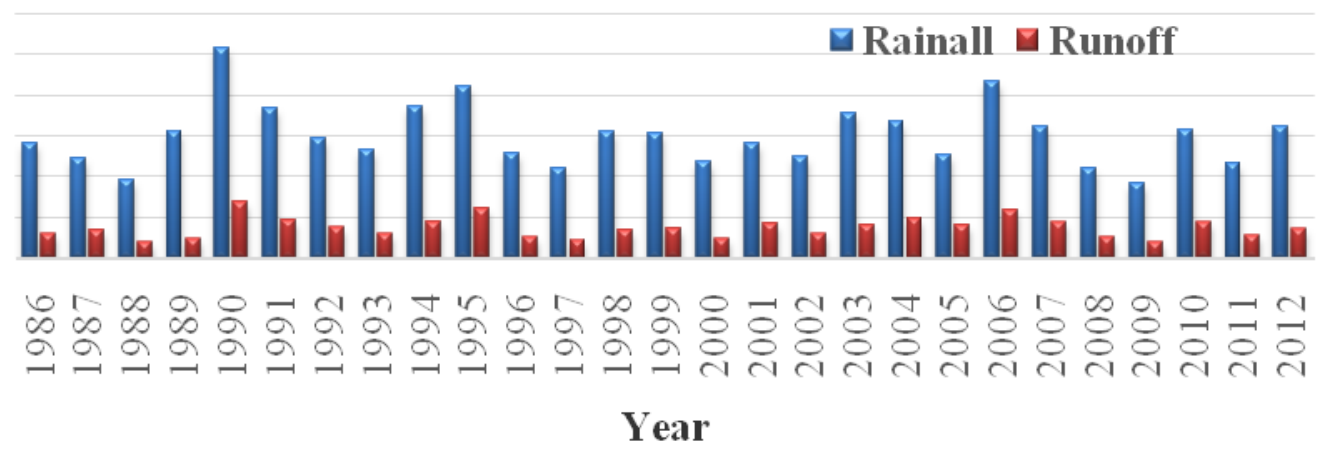


Fig.3

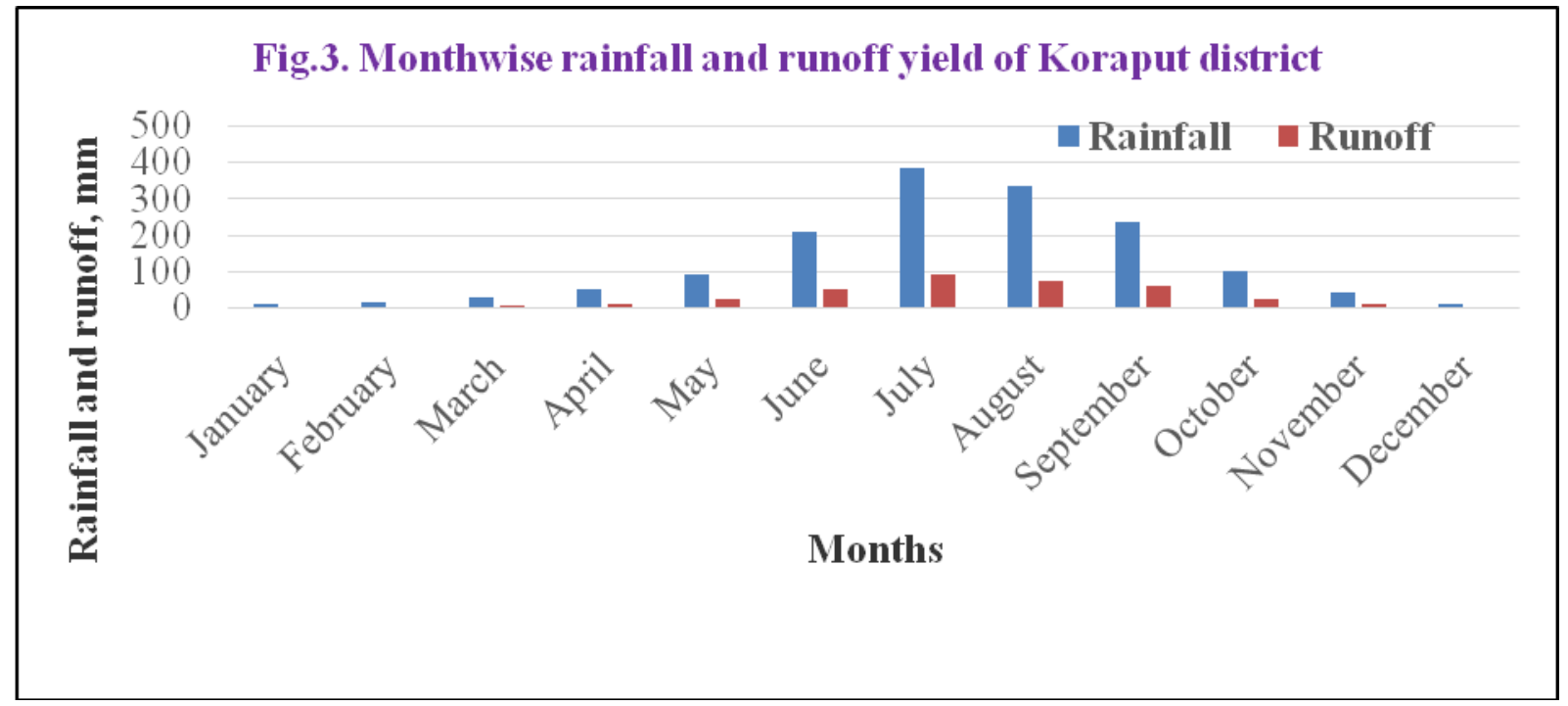

The present study reveals that surface runoff potential can be effectively computed using SCS-CN method, and the information on surface runoff potential estimated will immensely help for understanding rainfallrunoff relationship, water budgeting and water resources applications/planning of water harvesting structures. In addition, effective land use planning and watershed management can be carried out to have suitable crop plan of Koraput district for better agricultural sustainability in the region.

\section{References}

Amutha, R and Porchelvan, P. 2009. Estimation of Surface Runoff in Malattar Sub-Watershed using SCSCN method. Journal of Indian Society of Remote Sensing, 37: 291-304.

Government of Odisha. 2012. Odisha Agricultural Statistics 2010-11, Agriculture Department, Bhubaneswar.

Mishra, S. K, Tyagi, J. V, Singh, V.P and Singh, R. 2006. SCS-CN-based modeling of sediment yield; J. Hydrol. 324:301-322.

Muthu, A. C. Lalitha and Santhi, M. Helen 2015. Estimation of Surface Runoff
Potential using SCS-CN Method Integrated with GIS. Indian Journal of Science and Technology, 8(28):1-5.

Naik, B.S., Paul, J. C., Panigrahi, B. and Sahoo, B. C. (2014). Agroclimatic situation and profitability study of traditional cropping pattern in Koraput district in Eastern Ghat Region of Odisha. Journal of Soil and Water Conservation, 13 (3): 277-281.

Naik, B. S., J. C. Paul, B. Panigrahi, and B. C. Sahoo. 2015. Soil erosion assessment from farming lands of Eastern Ghat Region of Odisha. Ind. J. of Soil Cons., 43: 33-37.

Nagarajan, N, Poongothai, S. and Arutchelvan, V. 2013. Impact of land use/land cover changes on surface runoff from a rural watershed, Tamilnadu, India", Int. J. Water, 7:122-141.

Panigrahi, D., Mohanty, P. K., Acharya, M. and Senapati, P. C. 2010. Optimal utilization of natural resources for agricultural sustainability in rainfed hill plateaus of Odisha. Agricultural Water Management, 97(7): 1006-1016.

Somashekar, R. K., Ravikumar, P, Sowmya, S.V. and Dar, M.A. 2011. Runoff 
Estimation and Morphometric Analysis for Hesaraghatta Watershed Using IRS-1D LISS III FCC Satellite Data. Journal of the Indian Society of Remote Sensing, 39(1): 95-106.

Subramanya K. Engineering Hydrology, Tata McGraw Hill, Education, 1994.
USDA-SCS-CN Method 1972. A Method for Estimating Volume and Rate of Runoff in Small watersheds; SCS-TP-149, U.S. Department of Agriculture, Soil Conservation Service, Washington, DC.

\section{How to cite this article:}

Naik, B. S., J. C. Paul, B. Panigrahi, B. C. Sahu, A. P. Sahu and Ravi Dupdal. 2021. Surface Runoff Assessment of Koraput District in Eastern Ghats High Land Zone of Odisha. Int.J.Curr.Microbiol.App.Sci. 10(02): 2110-2117. doi: https://doi.org/10.20546/ijcmas.2021.1002.251 